\title{
Chemical Compositions of Dew and Scavenging of Particles in Changchun, China
}

\author{
Yingying $\mathrm{Xu},{ }^{1,2}$ Hui Zhu, ${ }^{3}$ Jie Tang, $^{2}$ and Yingzi Lin ${ }^{1}$ \\ ${ }^{1}$ Key Laboratory of Songliao Aquatic Environment, Ministry of Education, Jilin Jianzhu University, Xincheng Street, \\ District 5088, Changchun 130118, China \\ ${ }^{2}$ College of Resources and Environment, Jilin University, Qianjin Street, District 2699, Changchun 130021, China \\ ${ }^{3}$ Key Laboratory of Wetland Ecology and Environment, Northeast Institute of Geography and Agroecology, \\ Chinese Academy of Sciences, Shengbei Street, District 4888, Changchun 130102, China \\ Correspondence should be addressed to Hui Zhu; zhuhui@neigae.ac.cn
}

Received 6 March 2015; Revised 30 April 2015; Accepted 1 May 2015

Academic Editor: Julio Diaz

Copyright (c) 2015 Yingying Xu et al. This is an open access article distributed under the Creative Commons Attribution License, which permits unrestricted use, distribution, and reproduction in any medium, provided the original work is properly cited.

Dew and rain water were collected during 2013 and 2014 in Changchun, China. The dew was analyzed and the following parameters were measured: $\mathrm{pH}$, EC, TDS, major anions $\left(\mathrm{F}^{-}, \mathrm{Cl}^{-}, \mathrm{SO}_{4}{ }^{2-}\right.$, and $\left.\mathrm{NO}_{3}{ }^{-}\right)$, and major cations $\left(\mathrm{NH}_{4}{ }^{+}, \mathrm{Na}^{+}, \mathrm{K}^{+}, \mathrm{Ca}^{2+}\right.$, and $\left.\mathrm{Mg}^{2+}\right)$. The mean $\mathrm{pH}, \mathrm{EC}$, and TDS values of dew were comparable with the values for rainwater. The $\mathrm{pH}$ values of dew and rain were 6.72 and 6.16, respectively. Both EC $(308 \mu \mathrm{S} / \mathrm{cm})$ and TDS $(154 \mathrm{mg} / \mathrm{L})$ of dew were higher than those in rain samples. The concentration of main ions in dew was 1.5-5.7 times higher than levels in rainwater. The near-neutral $\mathrm{pH}$ values in dew were caused by the neutralization of acidity and buffering by the alkaline elements of soil origin $\left(\mathrm{Ca}^{2+}\right)$. This neutralization was confirmed by a strong correlation between the acidic ions $\left(\mathrm{SO}_{4}{ }^{2-}\right.$ and $\left.\mathrm{NO}_{3}{ }^{-}\right)$and the major cations $\left(\mathrm{Ca}^{2+}\right.$ and $\left.\mathrm{Mg}^{2+}\right)$. Natural dust made an important contribution to the ions present in dews, but the presence of sulfate concentrations that are notably higher than rain water (up to $1584.5 \mu \mathrm{eq} / \mathrm{L}$ ) indicated a significant contribution of anthropogenic sources. Dew has the ability to capture particulates, and the purifying effect on the underlying surface was obvious.

\section{Introduction}

Dew formation is a local phenomenon, significantly influenced by microclimatic environment, land profile, and favorable meteorological conditions. Dew can be easily absorbed by plant leaves and maintain leaf moisture in the canopy $[1,2]$. Ammonium and nitrate in dew are beneficial to plants $[3,4]$. Small aerosols in the atmosphere are the condensation nuclei in the process of dew formation and this wet deposition process is a major pathway transporting pollutants from the atmosphere to the biosphere $[5,6]$. Therefore, the chemical characters of dew are under the control of atmospheric air quality, and it can act as an indicator of the air quality of surface layer $[7,8]$.

With the rapid development of urban economy, air pollution has become increasingly serious. The gas from coal combustion, industrial emissions, and motor vehicle exhaust, as well as resuspended road dust leads to an increase in aerosols and especially $\mathrm{PM}_{10}$ (particulate matter with aerodynamic diameters less than $10.0 \mu \mathrm{m}$ ) and $\mathrm{PM}_{2.5}$ (particulate matter with aerodynamic diameters less than $2.5 \mu \mathrm{m})$ content. Air pollution has attracted much interest during the past decade for its harmful impact on health risk, visibility, and even global climate $[9,10]$. Huo et al. [11] and $\mathrm{Hu}$ et al. [12] concluded that particles and gases can be removed efficiently from the atmosphere by rain. As an important pathway of wet deposition, atmospheric aerosols acted as the condensation nuclei and were removed during the night as vapor condensed, and dew played an important role in air purification. Takenaka et al. [13] found that most nitrite and ammonium ions included in dew were decomposed when dew was dried. The concentrated ammonium nitrite aqueous solution is unstable and can decompose to $\mathrm{N}_{2}$ and $\mathrm{H}_{2} \mathrm{O}$. During the drying process of dew, nitrite and ammonium 
would be concentrated and react to form $\mathrm{N}_{2}$. As a result, nitrite and ammonia in the dried dew are lost, and therefore, dew can thoroughly remove nitrite and ammonium ions.

Dew has attracted great interest and dew levels have been extensively studied [14-17]. These studies have shown that the amount of dew water is smaller than the amount of rain water, but the condensation times are more frequent. Chemical composition in urban dew is closely related to the atmospheric precipitation $[5,18]$. Dew always condenses in the range of $0-2 \mathrm{~m}$ above the surface, and particulates at this level have a more direct and strong influence on human health than at any other level. Variation in dew chemical compositions can reflect the characteristics of particle pollution to some extent. However, the chemistry of urban dew has received little attention.

Changchun city is the capital of Jilin province $\left(43^{\circ} 05^{\prime} \mathrm{N}\right.$ $45^{\circ} 15^{\prime} \mathrm{N}, 124^{\circ} 18^{\prime} \mathrm{E}-127^{\circ} 02^{\prime} \mathrm{E} ; 450 \mathrm{~km}$ from the sea), and it is the most important industrial center of automobile, photovoltaic, biopharmaceutical, and railway vehicle production. With the rapid urbanization and motorization of Changchun in recent years, air pollution remains at a much higher level than in the past. The objectives of the present study are (1) to analyze the chemical characters of dew and rain in Changchun city and (2) to reveal the scavenging process of underlying surface particulates by dew.

\section{Methodology and Measurements}

2.1. Sampling Site. Dew and rain were collected at Jilin University, which is located in the southwest area of Changchun city. The crowds and traffic are concentrated, and the population density is approximately 1000 people $\mathrm{km}^{2}$. The area is characterized by the continental monsoon climate and the average annual temperatures vary from $-15^{\circ} \mathrm{C}$ in January to $25^{\circ} \mathrm{C}$ in August. Rain precipitation is in the range of 522$615 \mathrm{~mm}$ per year. Changchun has four distinct seasons. Compared to the strong winds in spring and the freeze in winter, summer and autumn are accompanied with a high humidity and obvious temperature difference between day and night, and the wind speed is always below $2 \mathrm{~m} / \mathrm{s}$. The climatic conditions are therefore suitable for dew condensation. Thus, the occurrence of dew is common in the summer and autumn seasons at the present site. Dew samples were collected during the peak summer and autumn period (June to September in 2013 and 2014).

2.2. Sample Collection and Analysis. The results of dew samples collected by different collection surfaces vary substantially [27]. A polytetrafluoroethylene (PTFE) surface has been shown to be a proper collection surface for dew collection [28]. In this study, dew water was collected in precleaned PTFE bottles with a $250 \mathrm{~mL}$ capacity. PTFE bottles were placed in the green belt region along the campus road (approximately $1.0 \mathrm{~m}$ above ground level). To avoid the effects of haze or rain on the particle concentration of air, all dew water samples were collected before sunrise on the nonrainy and nonhazy days. Rain water was collected on rainy days during the experiment period using precleaned PTFE bottles with a $500 \mathrm{~mL}$ capacity. Rain collectors were placed on the balcony of the laboratory building (approximately $15 \mathrm{~m}$ above ground level). A total of 24 dew samples and 18 rain samples were collected during the experimental period.

All collected samples were analyzed to determine $\mathrm{pH}$ (LA-pH10, USA), electrical conductivity (EC), and total dissolved solids (TDS) (LA-EC20, USA). Measurements were done in duplicate and were conducted immediately to avoid any contamination or changes during their preservation. The acceptable difference between duplicate analyses was 0.03 for $\mathrm{pH}$ values and $<2 \mu \mathrm{S} / \mathrm{cm}$ for EC. All the dew and rainwater samples were filtered through $0.45 \mu \mathrm{m}$ membrane filters and stored at approximately $4^{\circ} \mathrm{C}$ for further chemical analysis. Major cations $\left(\mathrm{Ca}^{2+}, \mathrm{Mg}^{2+}, \mathrm{Na}^{+}, \mathrm{K}^{+}\right.$, and $\left.\mathrm{NH}_{4}{ }^{+}\right)$and anions $\left(\mathrm{F}^{-}, \mathrm{Cl}^{-}, \mathrm{NO}_{3}{ }^{-}\right.$, and $\left.\mathrm{SO}_{4}{ }^{2-}\right)$ were analyzed with an ion chromatograph (Shimadzu LC-20AD, Japan). A Shim-pack IC-C1

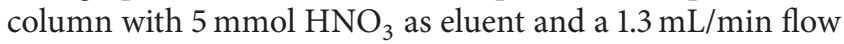
rate were used to analyze $20 \mu \mathrm{L}$ of each sample for cations. A Shim-pack IC-A3 column with $8.0 \mathrm{mmol}$ p-hydroxybenzoic acid (PHBA), $3.2 \mathrm{mmol}$ Bis-Tris, and $50 \mathrm{mmol}$ boric acid as eluent and $1.5 \mathrm{~mL} / \mathrm{min}$ flow rate was used to analyze $50 \mu \mathrm{L}$ of each sample for anions.

In order to reveal the scavenging process of underlying surface particulates by dew, experiments were carried out on July 21-22, 2013, July 25-26, 2014, and August 13-14, 2014. Collectors (PTFE bottles) were placed in the green belt region at 18:00, and one of the collectors was analyzed every hour from 19:00 till 6:00 the next day. The hourly data of the near surface $\mathrm{PM}_{10}$ and $\mathrm{PM}_{2.5}$ concentrations from 18:00 till 7:00 of the next day were provided by the Changchun City Air Quality Monitoring Station. Meanwhile, the daily meteorological factors, including average wind speed $\left(\mathrm{m} \cdot \mathrm{s}^{-1}\right)$ during the condensation period and rainfall $(\mathrm{mm})$ were provided by the Changchun City Meteorological Station.

2.3. Data Analysis. The statistical analyses were carried out using SPSS version 16.0. To test the normal distributions of nocturnal wind speed and ionic concentrations of dew, Q-Q probability plots were employed. The $\mathrm{Ca}^{2+}, \mathrm{NH}_{4}{ }^{+}, \mathrm{NO}_{3}{ }^{-}$, and $\mathrm{SO}_{4}{ }^{2-}$ concentrations in dew as well as nocturnal wind speed on July 21-22, 2013, July 25-26, 2014, and August 13-14, 2014, all followed a normal distribution. The ionic concentrations of dew and hourly nocturnal wind speed on July 21-22, 2013, July 25-26, 2014, and August 13-14, 2014, were analyzed using oneway ANOVAs, and the significance level was set to $P<0.05$. Least Significant Difference or Tamhane's T2 procedure was used to determine the significant differences between each group of concentrations and wind speed.

\section{Result and Discussion}

3.1. $p H, E C$, and TDS. As shown in Table 1, the dew $\mathrm{pH}$ and rain $\mathrm{pH}$ were in the range of 5.89-7.20 and 5.29-6.89, respectively. Dew $\mathrm{pH}$ is less acidic than rain, which is similar to the results found in some humid or urban sites (Table 2). Dew acidity is derived from $\mathrm{CO}_{2}$ absorption and the acidic aerosol dissolution during droplet growth [25]. Rain $\mathrm{pH}$ in these areas is lower because of the various quantities of acidic 
TABLE 1: Summary of $\mathrm{pH}$, electrical conductivity (EC), and total dissolved solids (TDS) of dew $(n=24)$ and rainwater samples $(n=18)$ collected over Changchun city during the experimental period in 2013 and 2014.

\begin{tabular}{|c|c|c|c|c|c|c|}
\hline & \multicolumn{3}{|c|}{$\operatorname{Dew}(n=24)$} & \multicolumn{3}{|c|}{ Rain $(n=18)$} \\
\hline & $\mathrm{pH}$ & $\mathrm{EC}(\mu \mathrm{s} / \mathrm{cm})$ & TDS (mg/L) & $\mathrm{pH}$ & $\mathrm{EC}(\mu \mathrm{s} / \mathrm{cm})$ & TDS (mg/L) \\
\hline Mean \pm SD & $6.72 \pm 0.33$ & 308 & 154 & $6.16 \pm 0.24$ & 95 & 48 \\
\hline Max & 7.20 & 552 & 276 & 6.89 & 163 & 81 \\
\hline Min & 5.89 & 250 & 125 & 5.29 & 52 & 26 \\
\hline
\end{tabular}

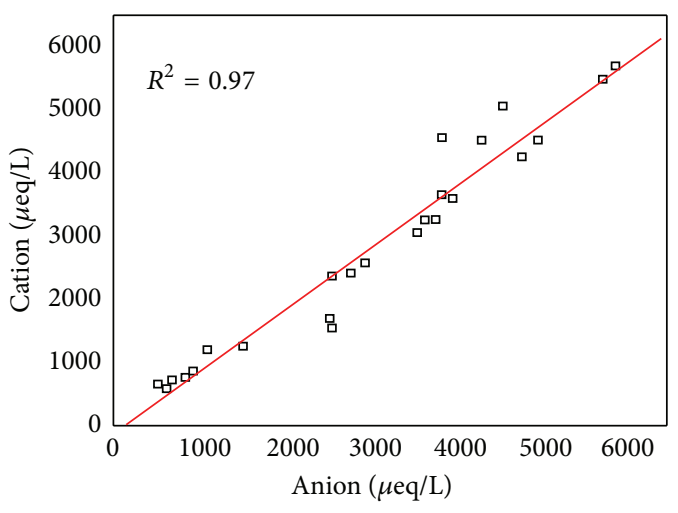

FIgURE 1: Correlation among sum of total cations (TC) and total anions (TA) in dew water of Changchun city.

species $\left(\mathrm{SO}_{2}\right.$ and $\left.\mathrm{NO}_{x}\right)$ influenced by human activities, such as fluctuating pollutant production and wind dispersion, or preceding rain events that clear out the aerosols [26]. In contrast, the $\mathrm{pH}$ values of dew were alkaline and were higher than that of rain water in the Negev desert [3]. The reason for this is that the levels of total dissolved ions (e.g., $\mathrm{Ca}^{2+}$ and $\mathrm{K}^{+}$) for dew in humid or urban environments were substantially lower than that in Negev. It is interesting to note that, in spite of the high sulfate concentrations, the presence of $\mathrm{Ca}^{2+}$ and ammonium ions in the solution increased the $\mathrm{pH}$. High $\mathrm{pH}$ values in dew may also be due to cooccurrence of dry deposition on a wet surface in the desert area.

The formation of acid dew is extremely important in accelerating the corrosion process. Acid dew can destroy the protective material on the plant leaf. In fact, compared to acid rain, acid dew could damage the surface of objects more seriously [27]. The average $\mathrm{pH}$ values for dew samples were 6.72 with a standard deviation of 0.33 ; therefore, no harmful acid dew was formed during the sampling period. Although the dew $\mathrm{pH}$ is acidic, plants can only be damaged when the $\mathrm{pH}$ of acid rain reaches around 3.0 [29]. Thus, the dew in Changchun city does not have the potential to damage or endanger the plant leaves.

The quality of the chemical analysis can be assessed by the ion balance (sum of total cations (TC) versus sum of total anions (TA)). TC and TA were well correlated in dew (Figure 1) and reflected the electroneutrality. The $R^{2}$ was 0.97 $(P<0.05)$, which indicated the effective neutralization of the acid forming anions (sulfate and nitrate) by the soluble cations (calcium and magnesium) and ammonium ions in the dew water.
As shown in Table 1, EC of dew during the sampling period ranged from $52 \mu \mathrm{s} / \mathrm{cm}$ to $163 \mu \mathrm{s} / \mathrm{cm}$. The mean EC and TDS were both higher than those in rain samples, reflecting higher total dissolved ions in dew. This may be attributed to the higher evaporation effect on dew samples compared to rain samples [24].

\subsection{Ionic Composition}

3.2.1. Dew/Rain Ratio. The decreasing order of ionic concentration in dew was $\mathrm{NH}_{4}{ }^{+}>\mathrm{SO}_{4}{ }^{2-}>\mathrm{Ca}^{2+}>\mathrm{NO}_{3}{ }^{-}>\mathrm{Na}^{+}>$ $\mathrm{Cl}^{-}>\mathrm{F}^{-}>\mathrm{K}^{+}>\mathrm{Mg}^{2+} \cdot \mathrm{NH}_{4}{ }^{+}(1536.9 \mu \mathrm{eq} / \mathrm{L})$ and $\mathrm{SO}_{4}{ }^{2-}$ $(1584.5 \mu \mathrm{eq} / \mathrm{L})$ were the most abundant cation and anion. $\mathrm{NH}_{4}{ }^{+}$and $\mathrm{SO}_{4}{ }^{2-}$ contributed $33.94 \%$ and $33.44 \%$ to the total ionic concentration, respectively (Figure 2). Neutralization by $\mathrm{Ca}^{2+}$ and $\mathrm{NH}_{4}{ }^{+}$was obvious in dew. The ratio $\mathrm{NH}_{4}{ }^{+}+$ $\mathrm{Ca}^{2+} / \mathrm{SO}_{4}{ }^{2-}+\mathrm{NO}_{3}{ }^{-}$was 1.3 , indicating the alkaline nature of both dew and rain water. The mean sum of cations and sum of anions in dew was 1944.9 and $2564.1 \mu \mathrm{eq} / \mathrm{L}$, respectively. However, the mean $\mathrm{pH}$ value was close to neutral. The slight excess of anions is probably due to the unmeasured concentrations of $\mathrm{HCO}_{3}{ }^{-}, \mathrm{CO}_{3}{ }^{2-}, \mathrm{NO}_{2}{ }^{-}, \mathrm{Br}^{-}$, and $\mathrm{PO}_{4}{ }^{2-}$.

The concentration of the various ions in dew is much higher than those in rain water with concentration ratios, dew/rain, being 3.82 for $\mathrm{NH}_{4}{ }^{+}, 2.68$ for $\mathrm{Ca}^{2+}, 3.13$ for $\mathrm{Na}^{+}$, 2.30 for $\mathrm{K}^{+}, 3.53$ for $\mathrm{Mg}^{2+}, 5.38$ for $\mathrm{SO}_{4}{ }^{2-}, 1.69$ for $\mathrm{NO}_{3}{ }^{-}, 2.91$ for $\mathrm{Cl}^{-}$, and 3.29 for $\mathrm{F}^{-}$. Similar high dew/rain ratios have also been reported in other areas (Table 3 ). The different chemical composition between dew and rain can be explained by the differences in the composition of high altitude (cloud level) and low altitude (ground level) aerosols and gases to which rain and dew are exposed [30]. Compared with the cloud level, the presence of natural dust and carbonates, as well as silicates around the ground contributes to the excess of ions in dew [24]. In addition, dew droplets are smaller than rain droplets, and dew is present at the surface nearly $10 \mathrm{~h} / \mathrm{d}$ and suffers a longer evaporation time. The higher ion concentration in dew also attributed to the higher evaporation effect on dew samples than rain by the nocturnal wind [3]. These factors lead to high ion concentration in dew $[19,31]$. As shown in Table 3, Beysens et al. [26] found that concentrations of cations $\left(\mathrm{Ca}^{2+}, \mathrm{Mg}^{2+}, \mathrm{Na}^{+}, \mathrm{K}^{+}, \mathrm{Zn}^{2+}\right.$, and $\left.\mathrm{Cu}^{2+}\right)$ and anions $\left(\mathrm{Cl}^{-}, \mathrm{NO}_{3}{ }^{-}\right.$, and $\left.\mathrm{SO}_{4}{ }^{2-}\right)$ were generally lower for dew than for rain in Bordeaux, France. The lower concentration in dew was due to the insignificant diffusion of minerals and coal combustion in the coastal area. The chemical composition of the dew closely related to the air quality of the underlying surface. The results implied that 


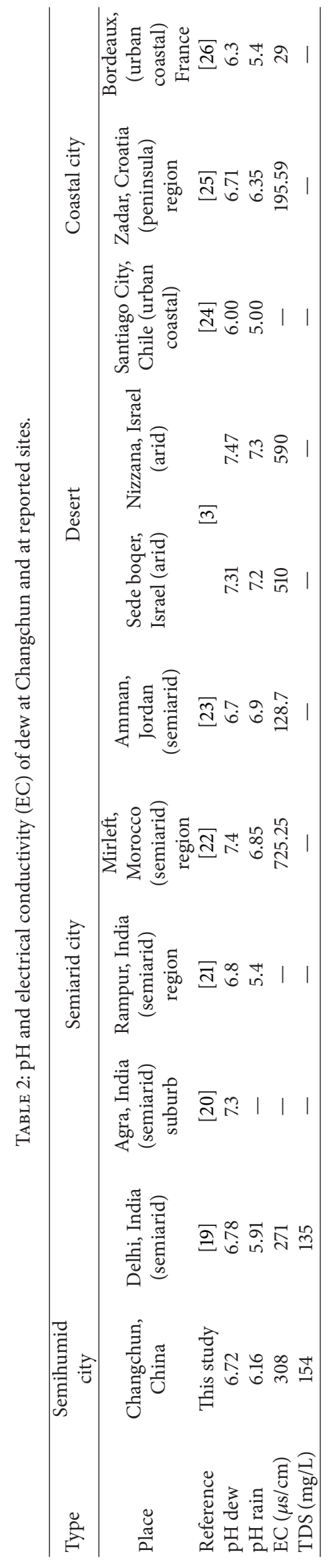




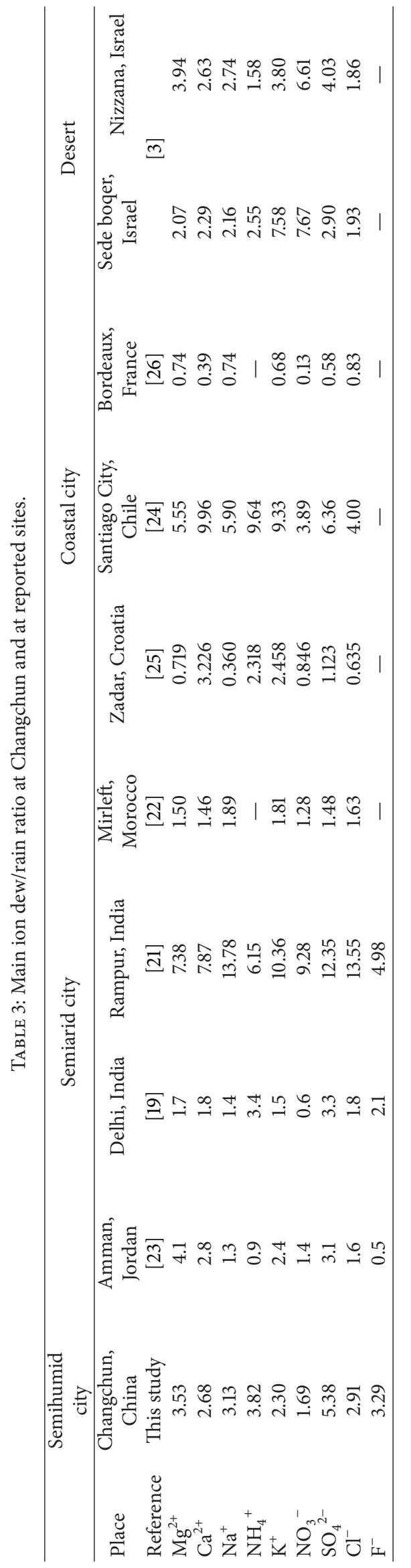


TABLE 4: Correlation coefficients among ionic constituents in dew water (italic font) and rainwater (bold font).

\begin{tabular}{|c|c|c|c|c|c|c|c|c|c|}
\hline \multirow{2}{*}{ Dew } & \multicolumn{9}{|c|}{ Rain } \\
\hline & $\mathrm{NH}_{4}^{+}$ & $\mathrm{Mg}^{2+}$ & $\mathrm{Ca}^{2+}$ & $\mathrm{K}^{+}$ & $\mathrm{Na}^{+}$ & $\mathrm{Cl}^{-}$ & $\mathrm{NO}_{3}^{-}$ & $\mathrm{F}^{-}$ & $\mathrm{SO}_{4}{ }^{2-}$ \\
\hline $\mathrm{NH}_{4}^{+}$ & & $0.75^{* *}$ & $0.70^{* *}$ & $0.96^{* *}$ & 0.54 & $0.72^{* *}$ & $0.93^{* *}$ & $0.88^{* *}$ & $0.94^{* *}$ \\
\hline $\mathrm{Mg}^{2+}$ & $0.78^{* *}$ & & $0.94^{* *}$ & $0.85^{* *}$ & $0.72^{* *}$ & $0.78^{* *}$ & $0.76^{* *}$ & $0.65^{*}$ & $0.79^{* *}$ \\
\hline $\mathrm{Ca}^{2+}$ & $0.72^{* *}$ & $0.95^{* *}$ & & $0.79^{* *}$ & $0.81^{* *}$ & $0.90^{* *}$ & $0.73^{* *}$ & $0.63^{*}$ & $0.85^{* *}$ \\
\hline $\mathrm{K}^{+}$ & $0.68^{*}$ & $0.85^{* *}$ & $0.79^{* *}$ & & $0.73^{* *}$ & $0.62^{*}$ & 0.45 & 0.51 & $0.75^{* *}$ \\
\hline $\mathrm{Na}^{+}$ & $0.65^{*}$ & $0.89^{* *}$ & $0.85^{* *}$ & $0.98^{* *}$ & & $0.75^{* *}$ & 0.47 & $0.65^{*}$ & $0.66^{*}$ \\
\hline $\mathrm{Cl}^{-}$ & $0.88^{* *}$ & $0.85^{* *}$ & $0.88^{* *}$ & $0.90^{* *}$ & $0.90^{* *}$ & & 0.56 & $0.79^{* *}$ & $0.75^{* *}$ \\
\hline $\mathrm{NO}_{3}{ }^{-}$ & $0.77^{* *}$ & $0.90^{* *}$ & $0.90^{* *}$ & $0.75^{* *}$ & $0.75^{* *}$ & $0.85^{* *}$ & & $0.89^{* *}$ & $0.95^{* *}$ \\
\hline $\mathrm{F}^{-}$ & $0.65^{*}$ & $0.80^{* *}$ & $0.70^{* *}$ & $0.65^{*}$ & $0.68^{*}$ & $0.67^{*}$ & $0.68^{*}$ & & $0.78^{* *}$ \\
\hline $\mathrm{SO}_{4}{ }^{2-}$ & $0.78^{* *}$ & $0.91^{* *}$ & $0.87^{* *}$ & $0.75^{* *}$ & $0.75^{* *}$ & $0.80^{* *}$ & $0.92^{* *}$ & $0.83^{* *}$ & \\
\hline
\end{tabular}

${ }^{* *}$ Correlation is significant at the 0.01 level. ${ }^{*}$ Correlation is significant at the 0.05 level.

analyzing the chemical characteristics of dew can provide reference for the assessment of air pollution and judgment of the quality of air.

3.2.2. Correlation Analysis. Correlation analyses were applied to assess the associations among different soluble ionic species (Table 4). A significant positive correlation was observed between $\mathrm{Ca}^{2+}$ and $\mathrm{Mg}^{2+}$ ( $r=0.95$ for dew and $r=0.94$ for rainwater), suggesting their common crustal source. Changchun is a typical inland city and the main ions were of continental origin. The large distribution is due to the various quantities of acidic species $\left(\mathrm{SO}_{2}\right.$ and $\left.\mathrm{NO}_{x}\right)$ and alkaline soil dust absorbed by water passing through the atmosphere. Natural dust makes an important contribution to the ions present in dews. The sources of $\mathrm{Ca}^{2+}$ and $\mathrm{K}^{+}$ are aerosols from dust, originating from soil, which are suspended in the lower layer of the atmosphere and brought to the condensation surface of the dew by the wind. Similarly, the acid forming anions $\mathrm{NO}_{3}{ }^{-}$and $\mathrm{SO}_{4}{ }^{2-}$ are closely correlated ( $r=0.92$ for dew and $r=0.95$ for rainwater), indicating their simultaneous release from anthropogenic sources. The $\mathrm{NO}_{3}{ }^{-}$and $\mathrm{SO}_{4}{ }^{2-}$ measured in dew water cannot be explained by the deposition of particulate matter. The very high concentrations of sulfate and nitrate present in the collected waters indicated that anthropogenic sources (e.g., coal combustion, industrial emission, and motor vehicle exhaust) also contributed significantly. On the basis of correlation coefficient values in dew water $\left(\mathrm{NH}_{4}{ }^{+}\right.$versus $\mathrm{NO}_{3}{ }^{-}=0.77$ and $\mathrm{NH}_{4}{ }^{+}$versus $\left.\mathrm{SO}_{4}{ }^{2-}=0.78\right)$ and in rainwater $\left(\mathrm{NH}_{4}{ }^{+}\right.$ versus $\mathrm{NO}_{3}{ }^{-}=0.93$ and $\mathrm{NH}_{4}{ }^{+}$versus $\left.\mathrm{SO}_{4}{ }^{2-}=0.94\right)$, it was understood that the dominant neutralization reactions led to the formation of $\left(\mathrm{NH}_{4}\right)_{2} \mathrm{SO}_{4}$ and $\mathrm{NH}_{4} \mathrm{NO}_{3}$ in dew and rainwater in this region. Calcium sulfate, calcium nitrate, magnesium sulfate, and nitrate are secondary neutralization products formed in dew water as indicated by the correlation matrix $\left(\mathrm{Ca}^{2+}\right.$ and $\mathrm{SO}_{4}{ }^{2-}: r=0.87 ; \mathrm{Ca}^{2+}$ and $\mathrm{NO}_{3}{ }^{-}: r=0.90$; $\mathrm{Mg}^{2+}$ and $\mathrm{SO}_{4}{ }^{2-}: r=0.91 ; \mathrm{Mg}^{2+}$ and $\left.\mathrm{NO}_{3}{ }^{-}: r=0.90\right)$. These correlations indicate that the diverse nature of neutralization reactions took place via interactions of atmospheric watersoluble gases and particulate matter in the dew water. This provides evidence that $\mathrm{Ca}^{2+}, \mathrm{Mg}^{2+}$, and $\mathrm{NH}_{4}{ }^{+}$ions played a major role in neutralizing the acid components in dew water.

3.3. Particle Removal Effect. Sulfate, nitrate, and ammonium from gas-particle conversion have been the main water soluble inorganic components of $\mathrm{PM}_{2.5}$, accounting for $85 \%$ of the total water-soluble inorganic ions concentration [12]. Hourly concentrations of ions $\left(\mathrm{Ca}^{2+}, \mathrm{NH}_{4}{ }^{+}, \mathrm{NO}_{3}{ }^{-}\right.$, and $\mathrm{SO}_{4}{ }^{2-}$ ), $\mathrm{PM}_{10}$, and $\mathrm{PM}_{2.5}$ during the dew condensation period are shown in Figure 4. The trend of dew ions and particulate matter concentration changed with synchronicity, which implied that except for the process of dry deposition by gravity, the vapor condensation process was accompanied by the removal of particulates. Rain and dew are both a form of wet deposition. $\mathrm{Hu}$ et al. found that $\mathrm{pH}$ and ion concentration of rain decreased during the precipitation process, indicating the occurrence of neutralizing effects [12]. The concentration of $\mathrm{Cl}^{-}, \mathrm{NO}_{3}{ }^{-}$, and $\mathrm{SO}_{4}{ }^{2-}$ decreased by $88 \%, 77 \%$, and $73 \%$, respectively, in the process of rain events. The purifying effects of rain in terms of mass concentration, ion concentrations, and element concentrations of particles are significant [11].

Precipitation affected the concentration of ions in dew. As shown in Figure 3, precipitation events occurred from 8 to 9 July 2013; the ions $\left(\mathrm{Ca}^{2+}, \mathrm{Mg}^{2+}, \mathrm{NH}_{4}{ }^{+}, \mathrm{NO}_{3}{ }^{-}\right.$, and $\mathrm{SO}_{4}{ }^{2-}$ ) in dew had lower concentrations on 11 July than on 7 July. Because crowds and traffic are concentrated at the experimental site, the vehicle exhaust and resuspended road dust increased in the daytime. This led to higher concentrations of ions in dew on July 12 than on July 11. After continuous precipitation from 13 to 16 July, dew ion concentrations decreased on 17 July. Precipitation removed particles especially effectively after the heavy rain event from the eighteenth to the twentieth, which led to the minimum ion concentrations in dew. Plentiful rainfall did not occur in the last ten days of July, and higher ionic concentrations were detected on July 31. $\mathrm{Ca}^{2+}, \mathrm{NH}_{4}{ }^{+}, \mathrm{NO}_{3}{ }^{-}$, and $\mathrm{SO}_{4}{ }^{2-}$ dew concentrations on August 13-14 and July 25-26, 2014, were higher than on $21-22$, July $2013(P<0.05$; Figure 4$)$. The last 

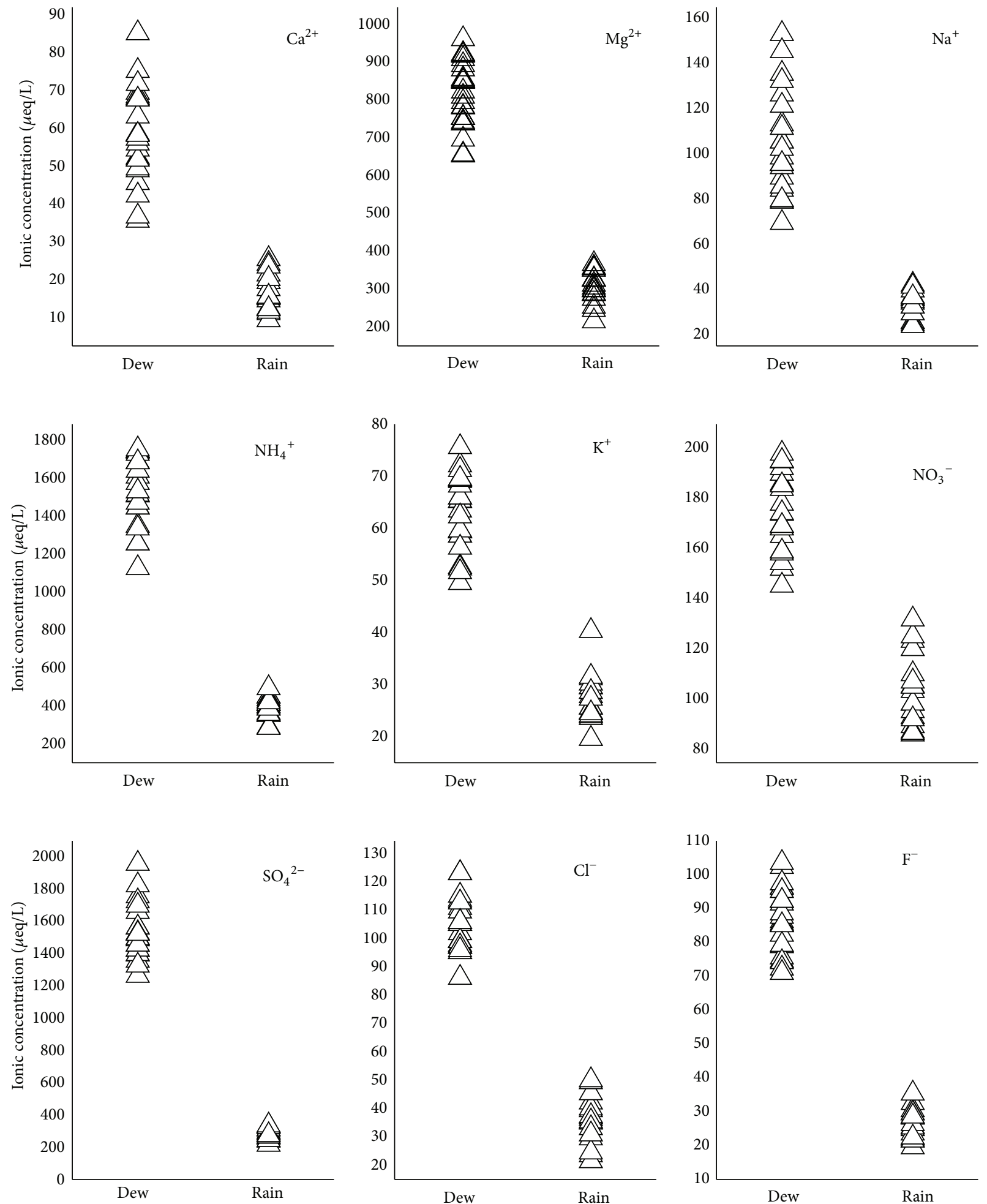

Figure 2: The ionic concentration of $\mathrm{NH}_{4}^{+}, \mathrm{Mg}^{2+}, \mathrm{Ca}^{2+}, \mathrm{K}^{+}, \mathrm{Na}^{+}, \mathrm{Cl}^{-}, \mathrm{NO}_{3}^{-}, \mathrm{F}^{-}$, and $\mathrm{SO}_{4}{ }^{2-}$ of rain and dew in Changchun.

rain event happened on 6 August and on 20 July. The reason for the higher ionic concentration of dew is the longer period without rain. This shows that the dust that acts as the nuclei of dew is decreased by rain and that ion concentrations in dew also declined after the precipitation event.
Strong wind enhances the heat exchange and can homogenize the temperature quickly and thereby decrease the temperature below the dew point. However, it makes vapor diffuse rapidly. Figure 3 shows that the majority of dew days appeared on the days in which wind speed was between 


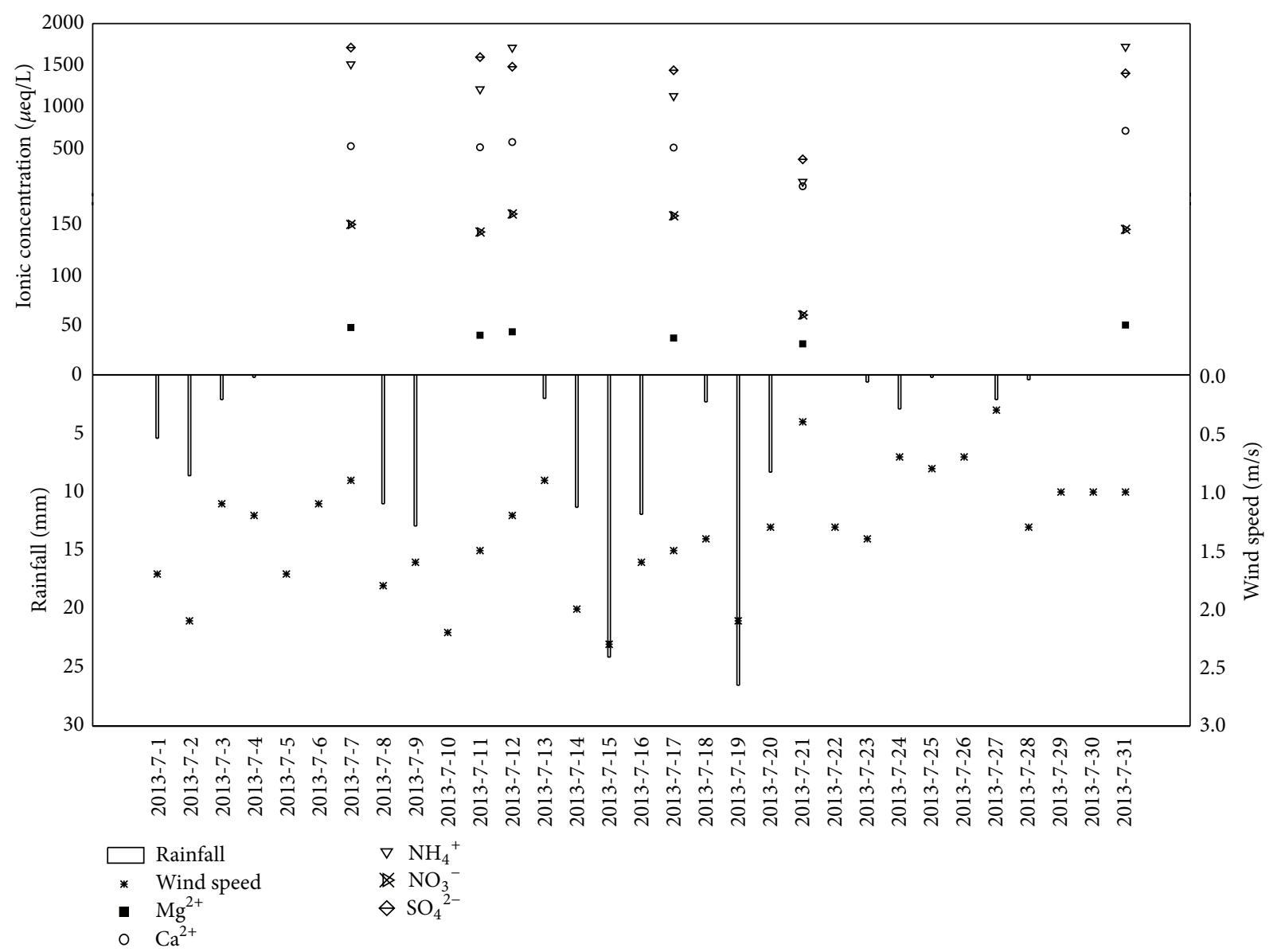

Figure 3: The ionic concentrations of dew, rainfall, and average wind speed during dew condensation for Changchun in July 2013.

$0.4 \mathrm{~m} / \mathrm{s}$ and $2.5 \mathrm{~m} / \mathrm{s}$ in Changchun. Therefore, the evaporation of dew cannot be ignored. Based on the statistical analysis, nocturnal wind speeds on July 25-26, 2014 were higher than on July 21-22, $2013(P<0.05)$, and no significant differences in nocturnal wind speed were observed between August 1314, 2014, and July 21-22, 2013. Meanwhile, $\mathrm{Ca}^{2+}, \mathrm{NH}_{4}^{+}, \mathrm{NO}_{3}{ }^{-}$, and $\mathrm{SO}_{4}{ }^{2-}$ concentrations in dew on August 13-14 and July 25-26, 2014, were higher than on July 21-22, $2013(P<0.05)$. This fact implies that nocturnal wind does not significantly affect the dew chemistry composition at our experiment site.

The ability of dew to remove particulates was far weaker than rain, because dew condensation only occurred near the surface and the dew amount is small. Compared with the efficiency of precipitation removal, removal of aerosols by dew has a delay. Therefore, the removal rate of ions by dew cannot be simply measured by misusing the beginning and ending chemical composition in the process of vapor condensation. The concentration of main ions continued to decline in a precipitation rain event [12]. The main ion $\left(\mathrm{Ca}^{2+}\right.$, $\mathrm{NH}_{4}{ }^{+}, \mathrm{NO}_{3}{ }^{-}$, and $\mathrm{SO}_{4}{ }^{2-}$ ) concentrations fluctuated during the vapor condensation. Dew formed on some hygroscopic nuclei near the ground. The lowering of ionic concentration with time can be explained by a dilution following the fact that condensation takes place around dust nuclei [3].
The meteorological characteristics associated with dew condensation during the night are a breeze and a higher relative humidity. Due to the formation of the radiation inversion layer near the surface, pollution diffusion and dilution are weak close to the underlying surface. Vehicle exhaust emissions and a large amount of atmospheric particulates such as dust on the ground cannot be easily spread or transferred. For example, on 13-14 August 2014, vapor began to condense at 18:00 and the process gave priority to the evaporation at 6:00. $\mathrm{PM}_{10}$ and $\mathrm{PM}_{2.5}$ concentration increased in the period of 18:00-22:00. The $\mathrm{Ca}^{2+}, \mathrm{NH}_{4}{ }^{+}$, $\mathrm{NO}_{3}{ }^{-}$, and $\mathrm{SO}_{4}{ }^{2-}$ concentration of dew increased during the same time period. From 22:00 to 1:00, $\mathrm{PM}_{10}$ and $\mathrm{PM}_{2.5}$ concentration began to decrease under the processes of gravity settling and vapor condensation. $\mathrm{Ca}^{2+}, \mathrm{NH}_{4}{ }^{+}, \mathrm{NO}_{3}{ }^{-}$, and $\mathrm{SO}_{4}{ }^{2-}$ concentration was given priority to gradually reduce (Figure 4). It is noteworthy that the rate of decrease for $\mathrm{PM}_{10}$ and $\mathrm{PM}_{2.5}$ was higher than the ions in dew (Figure 5). This indicates the strong ability of dew to capture atmospheric particulate matter and especially $\mathrm{PM}_{10} . \mathrm{PM}_{10}$ and $\mathrm{PM}_{2.5}$ concentrations began to slowly rise from 0:00 to 6:00. As the water vapor condensation approached saturation, dew condensation strength slowed and the atmospheric particulate removal effect was weakened. However, throughout the 


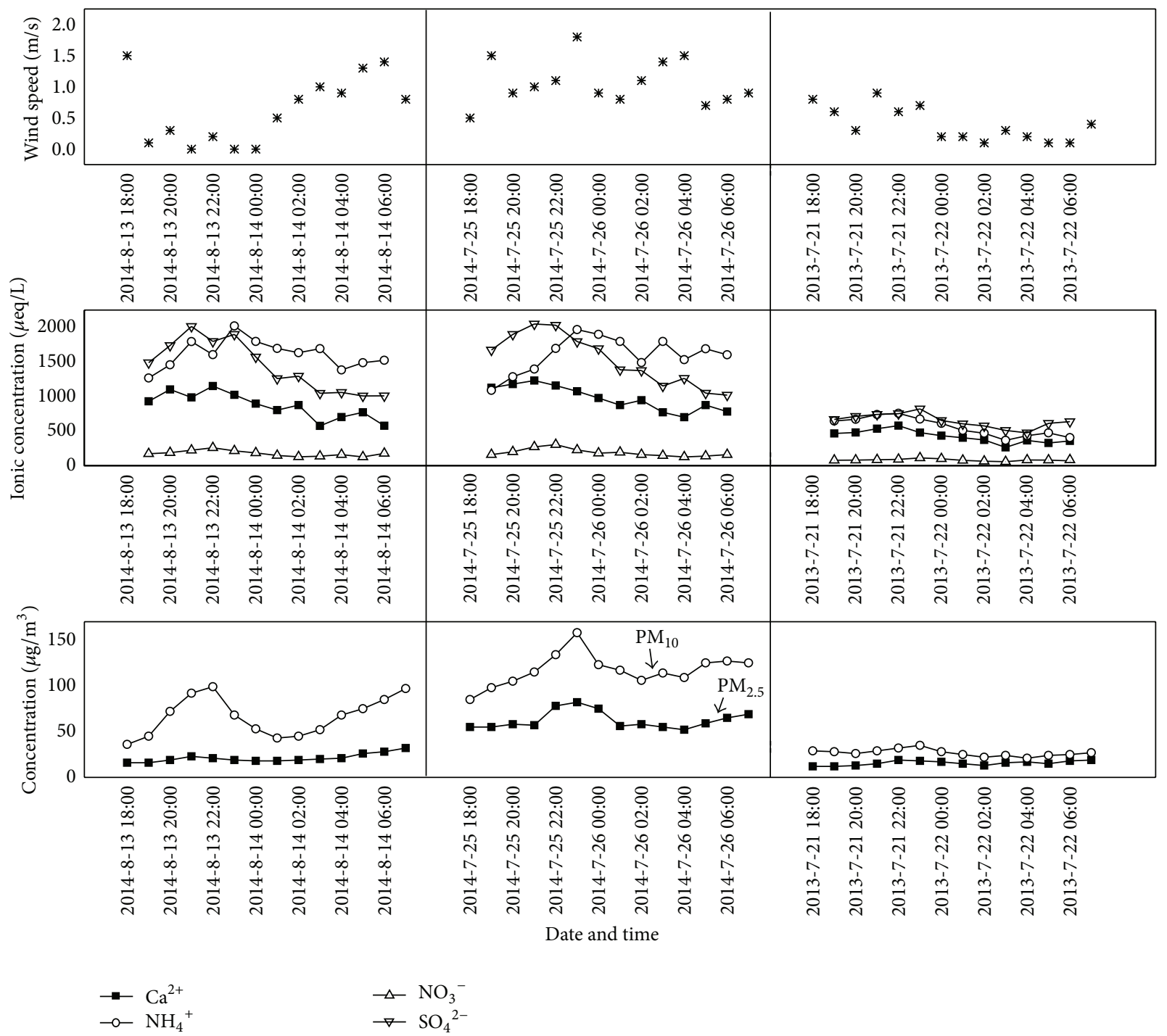

FIGURE 4: Hourly concentrations of ions, $\mathrm{PM}_{10}, \mathrm{PM}_{2.5}$, and wind speed during experimental period.

whole process of condensation, dew had the ability to capture particulates. The purification ability of dew was strong at the beginning and weakened at the end of the condensation process because the vapor condensed around the dust nuclei. The dew condensation process is very complex. It is affected by meteorological factors, types of nuclei, and near surface roughness, as well as other conditions. Thus, atmospheric particulate removal by dew requires further studying.

\section{Conclusion}

Rain and dew waters were collected and measured in Changchun city during 2013 and 2014. The concentrations of cations $\left(\mathrm{Ca}^{2+}, \mathrm{Mg}^{2+}, \mathrm{Na}^{+}, \mathrm{K}^{+}\right.$, and $\left.\mathrm{NH}_{4}^{+}\right)$and anions $\left(\mathrm{F}^{-}\right.$, $\mathrm{Cl}^{-}, \mathrm{NO}_{3}{ }^{-}$, and $\left.\mathrm{SO}_{4}{ }^{2-}\right), \mathrm{EC}(308 \mu \mathrm{S} / \mathrm{cm})$, and TDS $(154 \mathrm{mg} / \mathrm{L})$ measured in dews were considerably higher than those measured in rains. Dew exhibited near-neutral pH (to 7). The dew chemical composition revealed an abundance of the major cations $\mathrm{Ca}^{2+}$ and $\mathrm{Mg}^{2+}$ (continental origin) and the major anions $\mathrm{SO}_{4}{ }^{2-}$ and $\mathrm{NO}_{3}{ }^{-}$(anthropogenic origin). The acidity from dissolved $\mathrm{CO}_{2}, \mathrm{SO}_{x}$, and $\mathrm{NO}_{x}$ was mostly neutralized by $\mathrm{NH}_{4}^{+}$and $\mathrm{Ca}^{2+}$, thus giving an alkaline character to dew. Rain events affected the ions concentrations of dew. Dew events with the higher ionic concentration happened following longer periods without rain. In the whole process of condensation, dew had the ability to capture particulates. The purification ability of dew was strong at the beginning and weakened at the end of the condensation process.

\section{Conflict of Interests}

The authors declare that there is no conflict of interests regarding the publication of this paper.

\section{Acknowledgments}

The authors gratefully acknowledge funding support from the National Nature Science Foundation of China (41401229). 


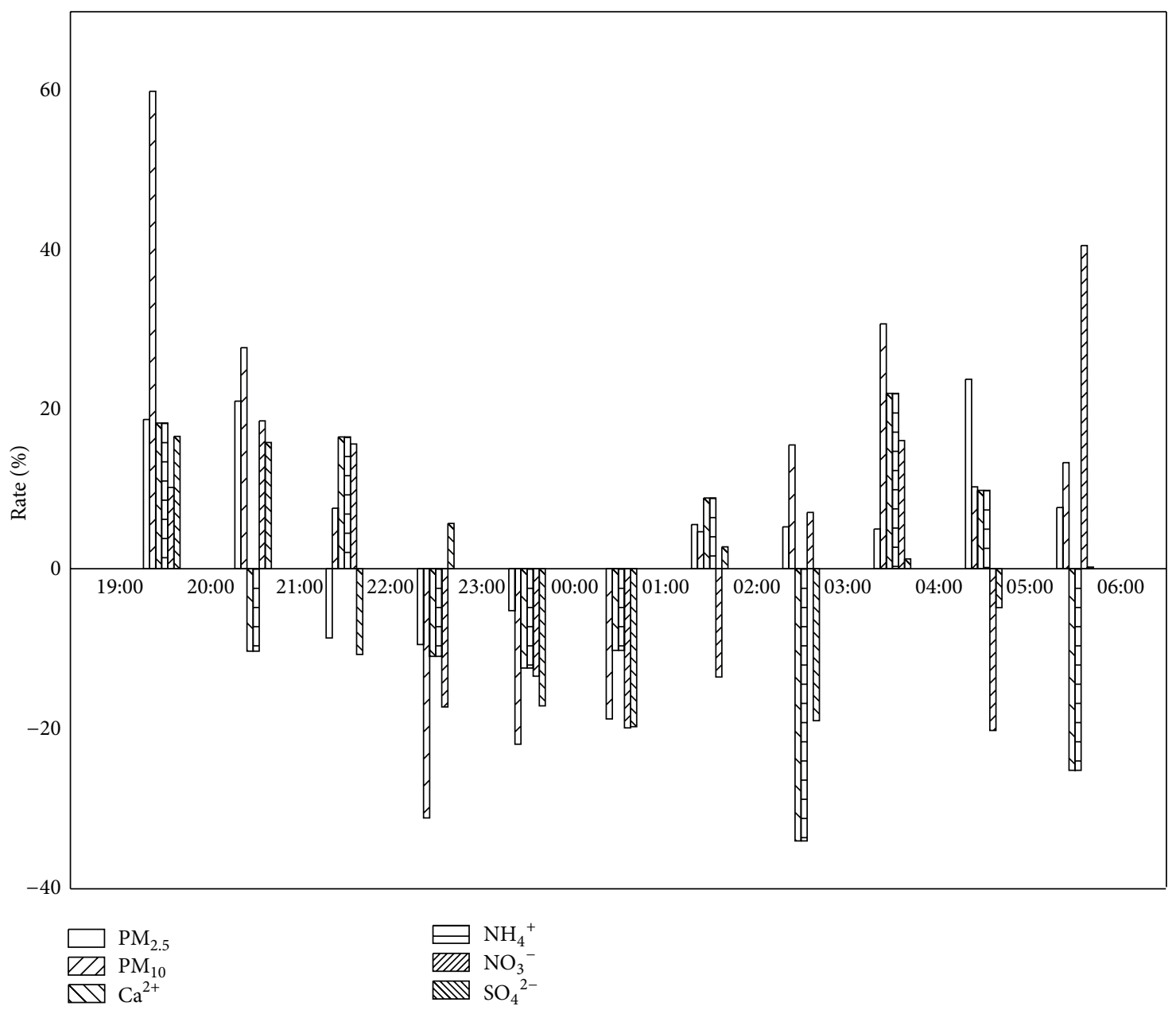

FIgURE 5: Hourly rate of concentration of ions, $\mathrm{PM}_{10}$, and $\mathrm{PM}_{2.5}$ on 13-14 August, 2014.

The authors express their gratitude to the Changchun City Air Quality Monitoring Station and the Changchun City Meteorological Station for providing meteorological data. The authors are indebted to the senior members of their team for their critical reading, kind remarks, and relevant suggestions. The authors thank LetPub (http://www.letpub.com/) for its linguistic assistance during the preparation of this paper.

\section{References}

[1] X.-F. Wen, X. H. Lee, X.-M. Sun et al., "Dew water isotopic ratios and their relationships to ecosystem water pools and fluxes in a cropland and a grassland in China," Oecologia, vol. 168, no. 2, pp. 549-561, 2012.

[2] H. F. Schmitz and R. H. Grant, "Precipitation and dew in a soybean canopy: spatial variations in leaf wetness and implications for Phakopsora pachyrhizi infection," Agricultural and Forest Meteorology, vol. 149, no. 10, pp. 1621-1627, 2009.

[3] G. J. Kidron and A. Starinsky, "Chemical composition of dew and rain in an extreme desert (Negev): cobbles serve as sink for nutrients," Journal of Hydrology, vol. 420-421, pp. 284-291, 2012.

[4] Y. Y. Xu, B. X. Yan, and H. Zhu, "Leaf dew contributes nutrients to paddies and improves rice growth," Acta Agriculturae Scandinavica Section B: Soil and Plant Science, vol. 63, no. 2, pp. 97-106, 2013.
[5] Z. Polkowska, M. Błaś, K. Klimaszewska, M. Sobik, S. Małk, and J. Namieśnik, "Chemical characterization of dew water collected in different geographic regions of Poland," Sensors, vol. 8, no. 6, pp. 4006-4032, 2008.

[6] M. A. Rubio, E. Lissi, N. Herrera, V. Pérez, and N. Fuentes, "Phenol and nitrophenols in the air and dew waters of Santiago de Chile," Chemosphere, vol. 86, no. 10, pp. 1035-1039, 2012.

[7] D. Beysens, M. Muselli, V. Nikolayev, R. Narhe, and I. Milimouk, "Measurement and modelling of dew in island, coastal and alpine areas," Atmospheric Research, vol. 73, no. 1-2, pp. 1-22, 2005.

[8] Y.-Y. Xu, B.-X. Yan, L.-X. Wang, H. Zhu, and S.-Y. Liu, "Metal concentrations of dew collected from Carex lasiocarpa in sanjiang plain," Wetland Science, vol. 9, no. 1, pp. 69-74, 2011 (Chinese).

[9] A.-S. Claeson, E. Lidén, M. Nordin, and S. Nordin, "The role of perceived pollution and health risk perception in annoyance and health symptoms: a population-based study of odorous air pollution," International Archives of Occupational and Environmental Health, vol. 86, no. 3, pp. 367-374, 2013.

[10] Y. L. Sun, G. S. Zhuang, A. H. Tang, Y. Wang, and Z. S. An, "Chemical characteristics of $\mathrm{PM}_{2.5}$ and $\mathrm{PM}_{10}$ in haze-fog episodes in Beijing," Environmental Science and Technology, vol. 40, no. 10, pp. 3148-3155, 2006. 
[11] M. Q. Huo, Q. Sun, P. Xie et al., "Relationship between atmospheric particles and rain water chemistry character," Environmental Science, vol. 30, no. 11, pp. 3159-3166, 2009.

[12] M. Hu, J. Zhang, and Z. J. Wu, "Chemical compositions of precipitation and scavenging of particles in Beijing," Science China Chemistry, vol. 48, no. 3, pp. 265-272, 2005.

[13] N. Takenaka, T. Suzue, K. Ohira, T. Morikawa, H. Bandow, and Y. Maeda, "Natural denitrification in drying process of dew," Environmental Science and Technology, vol. 33, no. 9, pp. 14441447, 1999.

[14] Y. Ye, K. Zhou, L. Song, J. Jin, and S. Peng, "Dew amounts and its correlations with meteorological factors in urban landscapes of Guangzhou, China," Atmospheric Research, vol. 86, no. 1, pp. 21-29, 2007.

[15] K. Richards, "Observation and simulation of dew in rural and urban environments," Progress in Physical Geography, vol. 28, no. 1, pp. 76-94, 2004.

[16] K. Richards, "Urban and rural dewfall, surface moisture, and associated canopy-level air temperature and humidity measurements for Vancouver, Canada," Boundary-Layer Meteorology, vol. 114, no. 1, pp. 143-163, 2005.

[17] I. Lekouch, K. Lekouch, M. Muselli, A. Mongruel, B. Kabbachi, and D. Beysens, "Rooftop dew, fog and rain collection in southwest Morocco and predictive dew modeling using neural networks," Journal of Hydrology, vol. 448-449, pp. 60-72, 2012.

[18] M. Takeuchi, H. Okochi, and M. Igawa, "Controlling factors of weak acid and base concentrations in urban dew water-comparison of dew chemistry with rain and fog chemistry," Bulletin of the Chemical Society of Japan, vol. 75, no. 4, pp. 757-764, 2002.

[19] S. Yadav and P. Kumar, "Pollutant scavenging in dew water collected from an urban environment and related implications," Air Quality, Atmosphere \& Health, vol. 7, no. 4, pp. 559-566, 2014.

[20] A. Lakhani, R. S. Parmar, and S. Prakash, "Chemical composition of dew resulting from radiative cooling at a semi-arid site in Agra, India," Pure and Applied Geophysics, vol. 169, no. 5-6, pp. 859-871, 2012.

[21] S. P. Singh, P. Khare, K. M. Kumari, and S. S. Srivastava, "Chemical characterization of dew at a regional representative site of North-Central India," Atmospheric Research, vol. 80, no. 4, pp. 239-249, 2006.

[22] I. Lekouch, M. Muselli, B. Kabbachi, J. Ouazzani, I. Melnytchouk-Milimouk, and D. Beysens, "Dew, fog, and rain as supplementary sources of water in south-western Morocco," Energy, vol. 36, no. 4, pp. 2257-2265, 2011.

[23] A. Jiries, "Chemical composition of dew in Amman, Jordan," Atmospheric Research, vol. 57, no. 4, pp. 261-268, 2001.

[24] M. A. Rubio, E. Lissi, and G. Villena, "Nitrite in rain and dew in Santiago city, Chile. Its possible impact on the early morning start of the photochemical smog," Atmospheric Environment, vol. 36, no. 2, pp. 293-297, 2002.

[25] I. Lekouch, M. Mileta, M. Muselli et al., "Comparative chemical analysis of dew and rain water," Atmospheric Research, vol. 95, no. 2-3, pp. 224-234, 2010.

[26] D. Beysens, C. Ohayon, M. Muselli, and O. Clus, "Chemical and biological characteristics of dew and rain water in an urban coastal area (Bordeaux, France)," Atmospheric Environment, vol. 40, no. 20, pp. 3710-3723, 2006.

[27] M. Chiwa, N. Oshiro, T. Miyake et al., "Dry deposition washoff and dew on the surfaces of pine foliage on the urban- and mountain-facing sides of Mt. Gokurakuji, western Japan," Atmospheric Environment, vol. 37, no. 3, pp. 327-337, 2003.
[28] M. A. Rubio, E. Lissi, and G. Villena, "Factors determining the concentration of nitrite in dew from Santiago, Chile," Atmospheric Environment, vol. 42, no. 33, pp. 7651-7656, 2008.

[29] Y. Q. Le, X. Z. Dai, and B. B. Zhou, "Experiment on the effect of simulated dew on plant," Shanghai Environment Science, vol. 17, no. 2, pp. 33-34, 1998 (Chinese).

[30] G. H. Wagner, K. F. Steel, and M. E. Peden, "Dew and frost chemistry at a mid-continent site, United States," Journal of Geophysical Research: Atmospheres, vol. 97, no. 18, pp. 2059120597, 1992.

[31] M. Muselli, D. Beysens, J. Marcillat, I. Milimouk, T. Nilsson, and A. Louche, "Dew water collector for potable water in Ajaccio (Corsica Island, France)," Atmospheric Research, vol. 64, no. 14, pp. 297-312, 2002. 

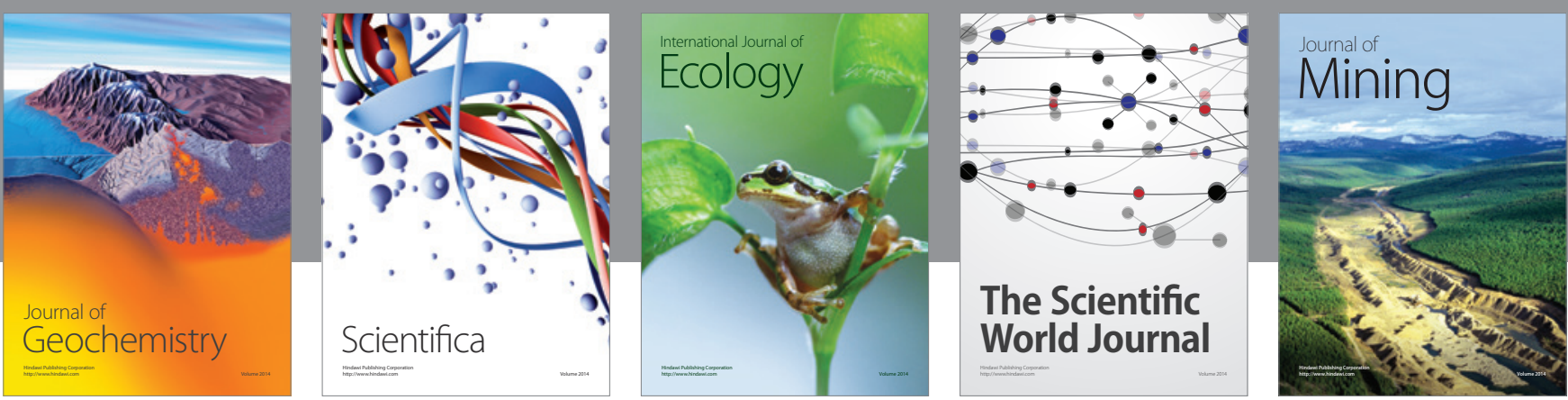

The Scientific World Journal
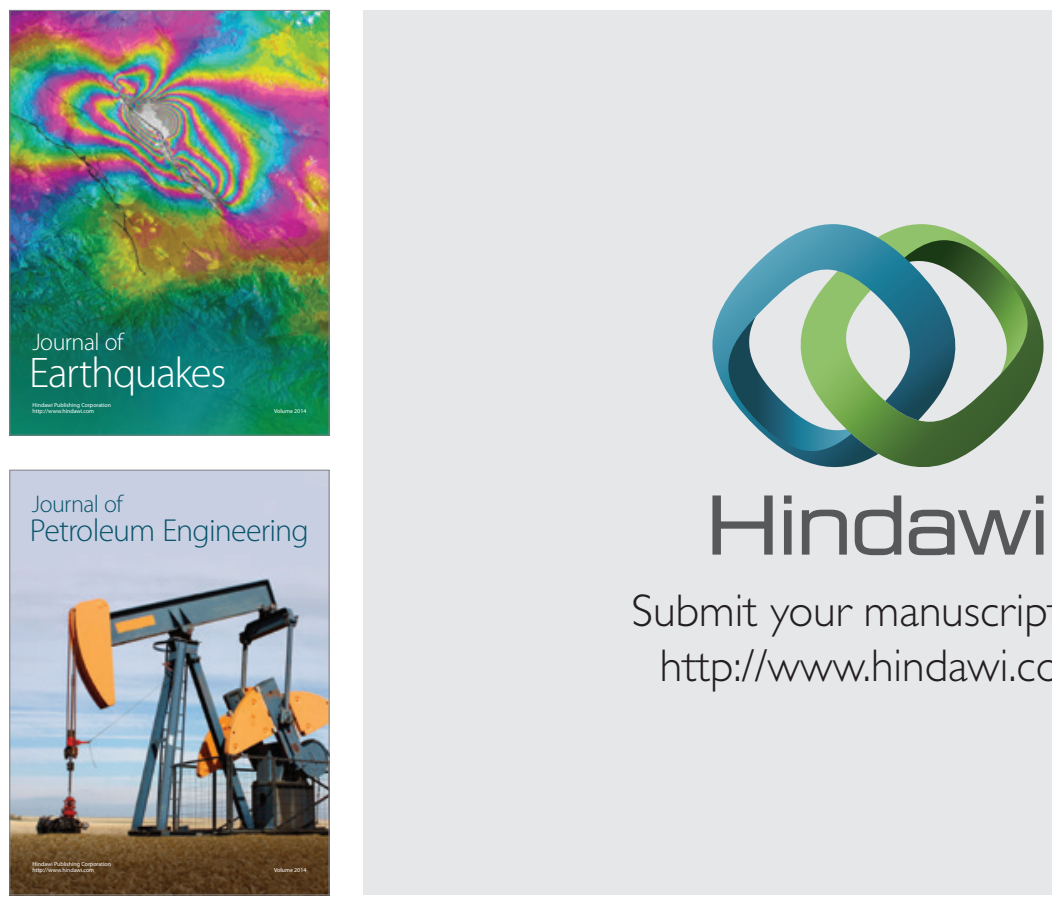

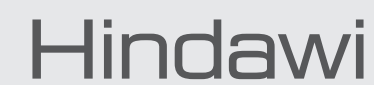

Submit your manuscripts at

http://www.hindawi.com
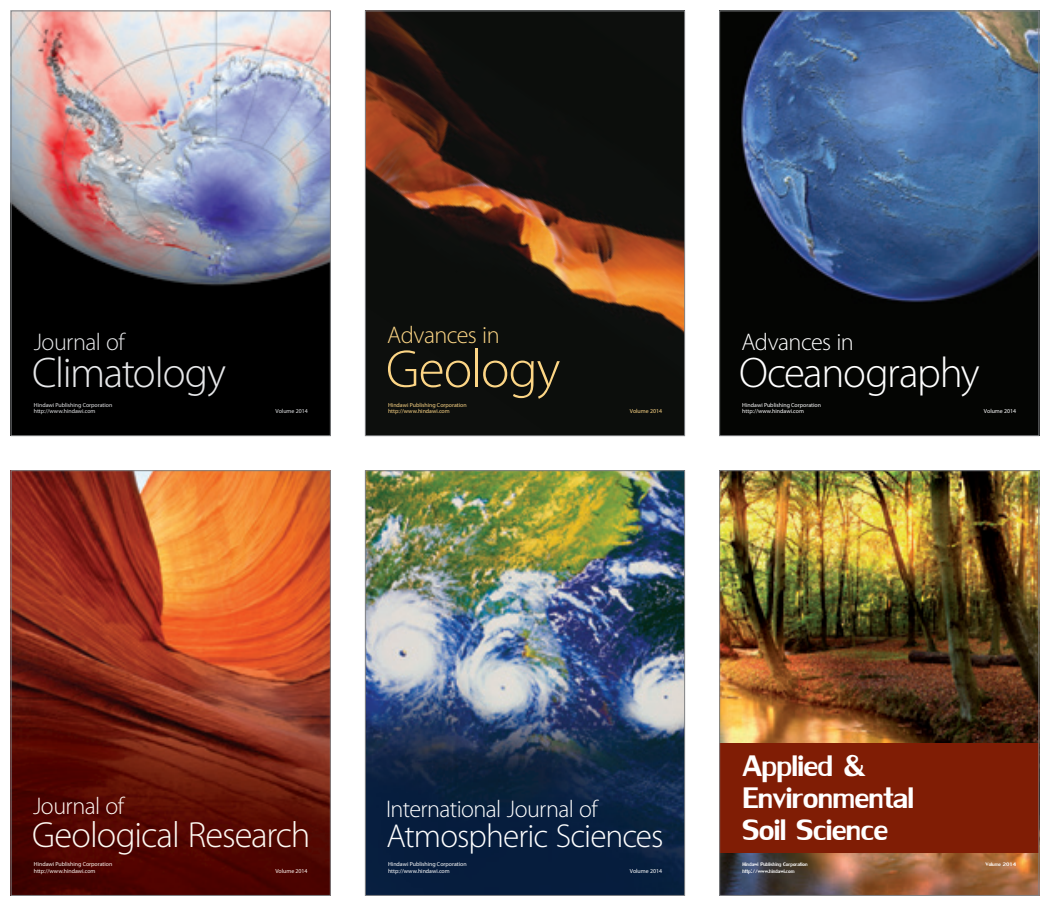
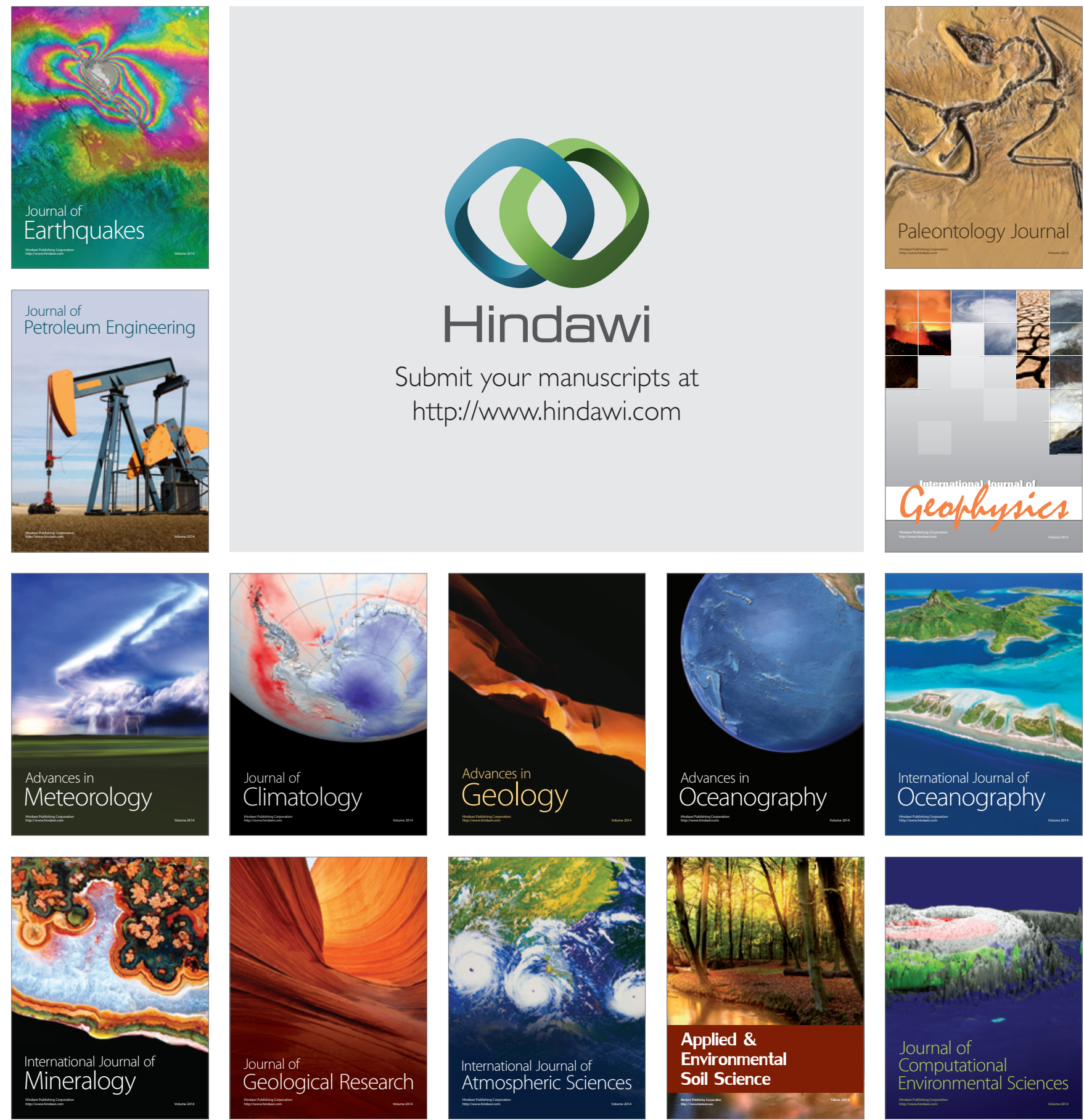